\title{
REGULATION OF GROWTH AND CELLULAR DIFFERENTIATION IN DEVELOPING AVENA INTERNODES BY GIBBERELLIC ACID AND INDOLE-3-ACETIC ACID ${ }^{1}$
}

\author{
Peter B. Kaufman, Louise B. Petering, and Paul A. Adams \\ Department of Botany, University of Michigan, Ann Arbor
}

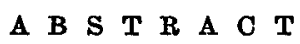

\begin{abstract}
Auxin (IAA) at physiological concentrations causes significant reduction of $\mathrm{GA}_{3}$-promoted growth in excised Avena stem segments. IAA is thus considered to be a gibberellin antagonist in this system. It was found to act non-competitively in repressing $\mathrm{GA}_{3}$-augmented growth in these segments. In intercalary meristem cells at the base of the elongating internode, $\mathrm{GA}_{3}$ blocks cell division activity and causes a marked increase in cell lengthening. IAA substantially promotes lateral expansion in comparable intercalary meristem cells, particularly in the vicinity of vascular bundles underlying the epidermis. It also alters the plane of cell division in differentiating stomata. IAA at high concentrations $\left(10^{-3}, 10^{-4} \mathrm{M}\right)$, in combination with $\mathrm{GA}_{3}$, overrides the effects of $\mathrm{GA}_{3}$ on cell lengthening, while with low concentrations of IAA $\left(10^{-9}, 10^{-10} \mathrm{M}\right)$, the effects of $\mathrm{GA}_{3}$ are clearly dominant. At intermediate concentrations of IAA $\left(10^{-6}, 10^{-7} \mathrm{M}\right)$, in the presence of $\mathrm{GA}_{3}$, the effects of this treatment on cell differentiation closely parallel the pattern of differentiation in untreated tissue. It is postulated that a lateral gradient of auxin and gibberellin could control cell expansion in long epidermal cells during intercalary growth of the internode.
\end{abstract}

RECENTLY, we reported that exogenously supplied gibberellic acid $\left(\mathrm{GA}_{3}\right)$ markedly accelerates the rate of intercalary growth and cell lengthening in elongating Avena internodes and in excised stem segments at concentrations as low as $3 \times 10^{-7} \mathrm{M}$ (Kaufman, 1965b, 1967). Indole-3-acetic acid (IAA), on the other hand, only accelerates growth and cell lengthening above $2 \times 10^{-4} \mathrm{M}$ (Kaufman, 1967), which is well above the concentration range of IAA that is of physiological significance in the plant (Thimann, 1937). Furthermore, IAA is capable of strongly suppressing the growthpromoting action of $\mathrm{GA}_{3}$ in these segments. These observations raise the following questions as to the nature of the interaction of these hormones: Is IAA active as a gibberellin antagonist within the physiological range for auxin $\left(10^{-5}\right.$ to $\left.10^{-11} \mathrm{M}\right)$ ? Do IAA and $\mathrm{GA}_{3}$ interact together in some way to control patterns of cellular differentiation in internodal epidermis? The results presented here indicate that an auxin such as IAA could be of physiological significance in the hormonal control of intercalary growth in this system through its interaction with gibberellin-type hormones.

${ }^{1}$ Received for publication 8 January 1969.

The authors thank Dr. Hiroshi Ikuma and Mr. James Weber of the Department of Botany, University of Michigan, for reading the manuscript and for many helpful suggestions.

This work was supported under auspices of NSF Grant 2688 and the Rackham School of Graduate Studies, University of Michigan, through NSF Grant GU-2295.
Materials ANd Methods-Next-to-last intelnodes (here designated as p-1; illustrated in Fig. 1, Kaufman, 1965a) in 45-50-day-old shoots of Avena sativa 'Victory' were used in this study. For growth experiments, the basal intercalary meristem portion of $\mathrm{p}-1$ internode was excised and the stem segments (I.M. segments) were incubated in water or hormone solution as cited in Kaufman, Ghosheh, and Iliuma (1968). These segments were kept at $23 \mathrm{C}$ for periods up to $72 \mathrm{hr}$ in 16-hr-light, 8-hr-dark (24-hr cycles). Net growth in length was measured every $24 \mathrm{hr}$.

For light microscopy studies, excised Avena shoots were incubated in the same environmental regime cited above. P-1 internode was exposed directly to the hormone solution; i.e., the sheath surrounding this internode was excised and the shoot supported in a 4-mm i.d.-glass tube. Shoots were removed periodically and the epidermis nicked with a razor blade at the desired locus. The raised tissue was pulled back and stripped off with a pair of jeweler's forceps. Slices of epidermis were made by cutting thin tangential pieces off the internode surface. This procedure was used primarily for the IAA-treated shoots. Both peels and slices were stained with $1 \%$ acetocarmine for $5 \mathrm{~min}$, then examined and photographed. Photomicrographs were made with Adox KB-14 or Panatomic X $35-\mathrm{mm}$ film.

Indole-3-acetic acid was obtained from Sigma Chemical Co., St. Louis, Mo. Gibberellic acid was kindly supplied by Dr. Douglas Broadbent, 


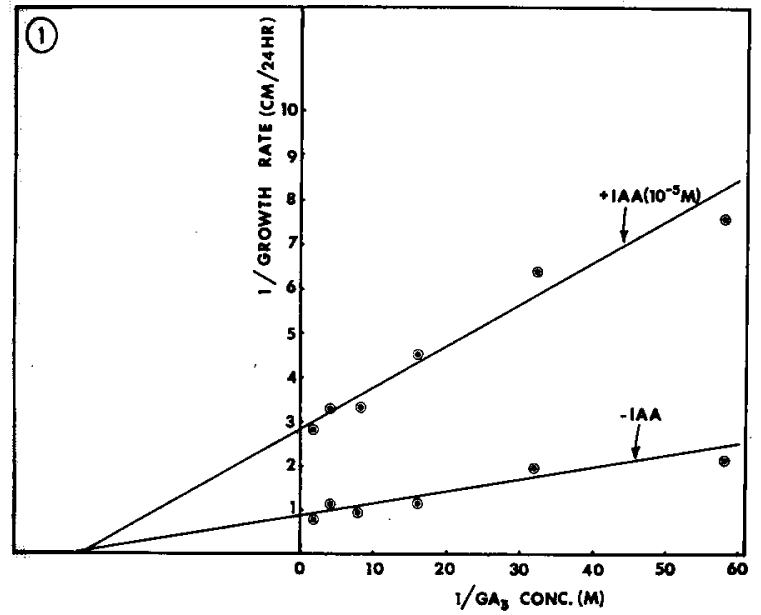

Fig. 1. Lineweaver-Burk plot, showing the effect of an inhibitory concentration of IAA $\left(10^{-5} \mathrm{M}\right)$ on the linear growth rate of $\mathrm{GA}_{3}$-treated Avena stem segments. $\mathrm{GA}_{3}$ was used in the concentration range of 0.15 to $0.5 \mu \mathrm{M}$.

Imperial Chemical Industries, Ltd., England. 'Victory' oats were obtained from the Swedish Seed Ass., Svalöf, Sweden.

REsults-Growth responses of isolated intercalary meristem segments to $\mathrm{GA}_{3}$ in the presence of varying concentrations of IAA-Table 1 indicates the concentration range of IAA which causes significant suppression of $\mathrm{GA}_{3}$-promoted growth in excised Avena I.M. segments. The amount of growth of control segments incubated in water averages $0.22 \mathrm{~cm}$. The net growth of segments treated with $\mathrm{GA}_{3}$ at levels of maximal growth response, such as $30 \mu \mathrm{M}$, is $1.75-2.00 \mathrm{~cm}$. When $\mathrm{GA}_{3}$ is used at this same concentration in the presence of varying concentration of IAA, the growth responses of I.M. segments (Table 1) indicate that IAA. clearly suppresses $\mathrm{GA}_{3}$-promoted growth at concentrations as low as $10^{-7} \mathrm{M}$ IAA. The amount of suppression increases between $10^{-i}$ and $10^{-3} \mathrm{M}$ IAA. It is clear from these data that IAA is indeed capable of suppressing $\mathrm{GA}_{3}$-enhanced growth in I.M. segments over a wide concentration range. It can suppress $\mathrm{GA}_{3}$-promoted growth as much as $49 \%$ at high concentration ( $10^{-3} \mathrm{M}$ IAA).

An experiment was then conducted to determine whether IAA inhibits $\mathrm{GA}_{3}$-promoted growth competitively or noncompetitively. Using a Lineweaver-Burk plot (Fig. 1), it is clear that IAA is acting in a non-competitive fashion. From this, we can say that IAA is probably not competing with $\mathrm{GA}_{3}$ at the same site, but it is acting at some other site( $\mathrm{s}$ ) which results in partial blocking of the action of $\mathrm{GA}_{3}$ on cell lengthening.

Cell differentiation in untreated internodal epidermis - In examining the mature internode of the oat plant, two gross morphological aspects of the epidermis are apparent (Fig. 2, 3). First, the stomata usually occur in epidermal cell files which lie adjacent to the position of vascular bundles ( $\mathrm{V}$ in Fig. 2, 3). In these files the long epidermal cells develop undulating wall thickenings, and they are shorter and wider than long cells in other files. Second, approximately eight cell files circumferentially away from the stomata files one finds cork-silica cell files whose long cells have less wall thickening and are considerably longer and thinner than those in the stomata files (IV in Fig. 2, 3). Thus, we see a gradient from wider, shorter cells with extensive wall thickenings to narrower, longer cells with little

TABLE 1. Net linear growth responses of Avena I.M. segments ${ }^{\mathrm{a}}$

\begin{tabular}{|c|c|c|c|}
\hline Treatment & $\begin{array}{l}\text { Net increase } \\
(\mathrm{cm})^{\mathrm{b}}\end{array}$ & $\begin{array}{c}\% \text { Promotion } \\
\text { over } \mathrm{H}_{2} \mathrm{O} \\
\text { control }\end{array}$ & $\begin{array}{l}\% \text { Inhibition } \\
\text { of IAA } \\
\text { treatment over } \\
\mathrm{GA}_{3} \text { treatment }\end{array}$ \\
\hline $\mathrm{H}_{2} \mathrm{O}$ control & $0.22 \pm 0.02$ & - & - \\
\hline $\mathrm{GA}_{\mathbf{s}}(30 \mu \mathrm{M})$ alone & $1.74 \pm 0.06$ & 690 & - \\
\hline IAA $\left(10^{-3} \mathrm{M}\right)$ alone & $0.35 \pm 0.03$ & 59 & - \\
\hline $\mathrm{GA}_{\mathbf{3}}(30 \mu \mathrm{M})+\mathrm{IAA}\left(10^{-3} \mathrm{M}\right)$ & $1.00 \pm 0.05$ & 355 & 48.7 \\
\hline $\mathrm{GA}_{8}(30 \mu \mathrm{M})+\mathrm{IAA}\left(10^{-4} \mathrm{M}\right)$ & $1.14 \pm 0.05$ & 417 & 39.5 \\
\hline $\mathrm{GA}_{3}(30 \mu \mathrm{M})+\operatorname{IAA}\left(10^{-5} \mathrm{M}\right)^{\mathrm{c}}$ & $1.32 \pm 0.04$ & 500 & 27.7 \\
\hline $\mathrm{GA}_{3}(30 \mu \mathrm{M})+\operatorname{IAA}\left(10^{-6} \mathrm{M}\right)^{\mathrm{c}}$ & $1.46 \pm 0.06$ & 564 & 18.5 \\
\hline $\mathbf{G A}_{\mathbf{3}}(30 \mu \mathrm{M})+\operatorname{IAA}\left(10^{-7} \mathbf{M}\right)^{\mathrm{c}}$ & $1.62 \pm 0.06$ & 637 & 8.0 \\
\hline $\mathrm{GA}_{3}(30 \mu \mathrm{M})+\operatorname{IAA}\left(10^{-8} \mathrm{M}\right)^{\mathrm{C}}$ & $1.72 \pm 0.06$ & 682 & 1.0 \\
\hline $\mathrm{GA}_{3}(30 \mu \mathrm{M})+\mathrm{IAA}\left(10^{-9} \mathrm{M}\right)^{\mathbf{c}}$ & $1.76 \pm 0.04$ & 700 & 0 \\
\hline $\mathrm{GA}_{\mathrm{z}}(30 \mu \mathrm{M})+\operatorname{IAA}\left(10^{-10} \mathrm{M}\right)^{\mathrm{e}}$ & $1.74 \pm 0.04$ & 690 & 0 \\
\hline
\end{tabular}

a 25 I.M. segments were used for each treatment. They were obtained from p-1 internodes $1.5-2.0 \mathrm{~cm}$ in length. Segments were incubated in a light (16-hr)-dark (8-hr) regime for $48 \mathrm{hr}$ and treated with water, IAA, GA $\mathrm{A}_{3}$ alone and in combinations indicated.

b Standard errors are expressed for each treatment.

c Physiological range of IAA (cf. Thimann, 1937). 


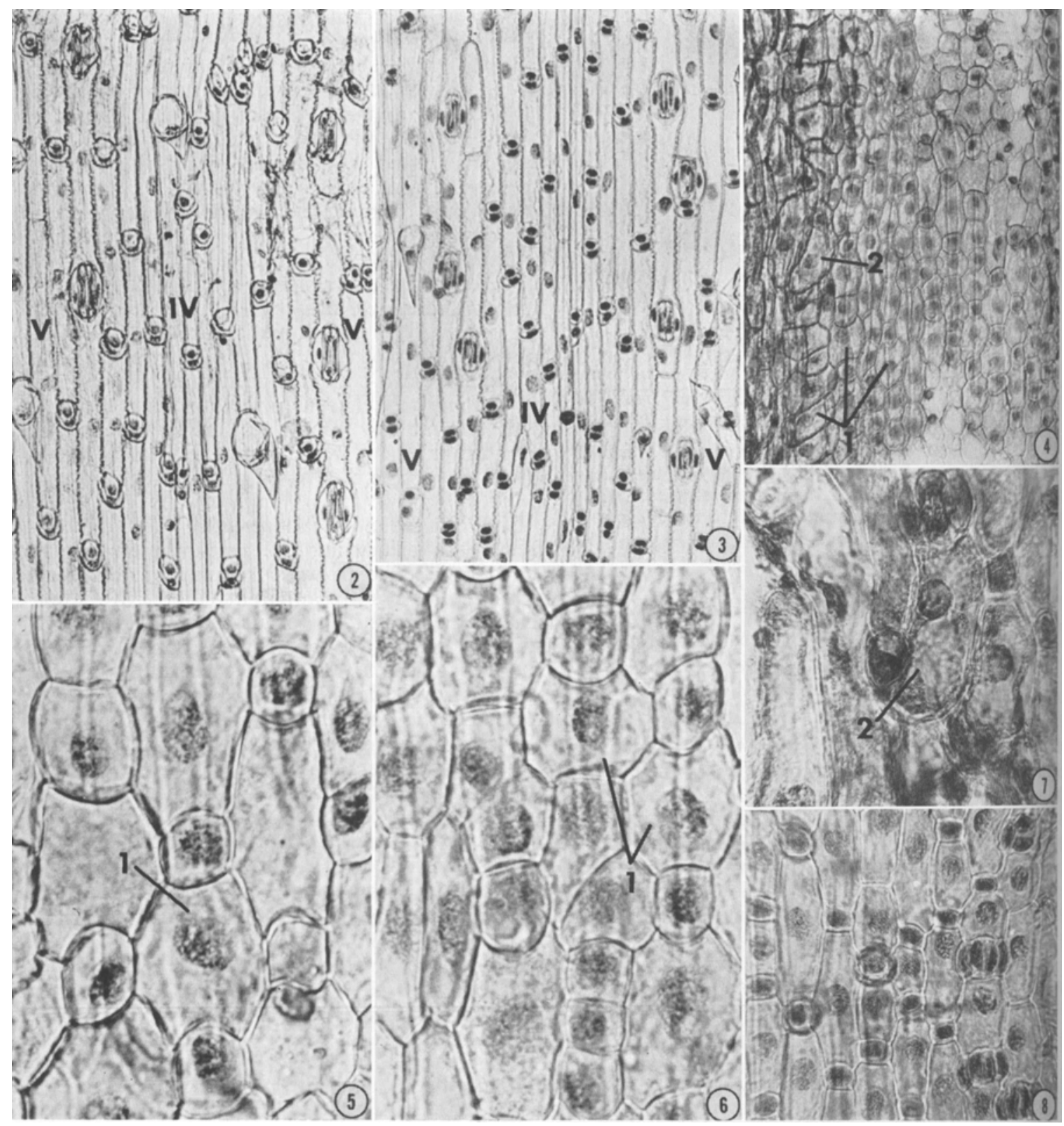

Fig. 2-8.-Fig. 2, 3. Untreated tissue, showing the morphological gradient from stomata files near vascular bundles (V) to cork-silica cell pair files between vascular bundles (IV). The former files have comparatively short and wide long cells whose walls are undulate, whereas the latter have long and narrow long cells with straight walls.-Fig. 4-8. IAA. treated epidermal tissue just above the I.M. which shows the following effects of the hormone: (1) promotion of lateral expansion, (2) distortion of cell expansion in localized regions, and (3) alteration of plane of cell division. Arrows indicate the particular effects in each photomicrograph. IAA was used at $10^{-3} \mathrm{M}$.-Fig. $2-4$. $\times 140 .-$ Fig. 5,6 . $\times 560 .-F i g .7$. $\times 280$. - Fig. $8 . \times 160$.

wall thickening as one progresses from stomata files to cork-silica cell files in the epidermal system. This pattern is quite subtle, but it is consistent and will serve as a useful "control" in comparison with patterns revealed in hormone-treated tissue.

The effects of $I A A$ and $G A_{3}$ on cell differentiation in internodal epidermis-The effects of IAA-IAA at high concentrations $\left(10^{-3}, 10^{-4} \mathrm{M}\right)$ increases lateral expansion of long epidermal cells proximate to the vascular bundles (cf. Fig. 4 with 2,3). The long cells balloon at the girth causing a reticulate pattern of the walls. Because of the ballooning and occasional longitudinal and oblique 
cell divisions, the continuity of the epidermal cell files is disrupted (Fig. 4-7). These effects are much less pronounced in short cells and in cells in files midway between the bundles.

In stomata files IAA not only promotes the lateral expansion of alternating long epidermal ells (Fig. 8), but it also causes a change in the plane of cell division in the guard cell mother cells (GCMC's) of developing stomata. For example, in lig. 9, 10 are shown young stomatal complexes in which IAA at $10^{-3} \mathrm{M}$ has caused the GCMC's to divide transversely instead of in the normal longitudinal direction. The alterations in plane of cell division can also include the GCMC's in which cell division is oblique as shown in Fig. 11, 12. These products of altered plane of cell division in GCMC's of IAA-treated internodes do not usually differentiate into normal

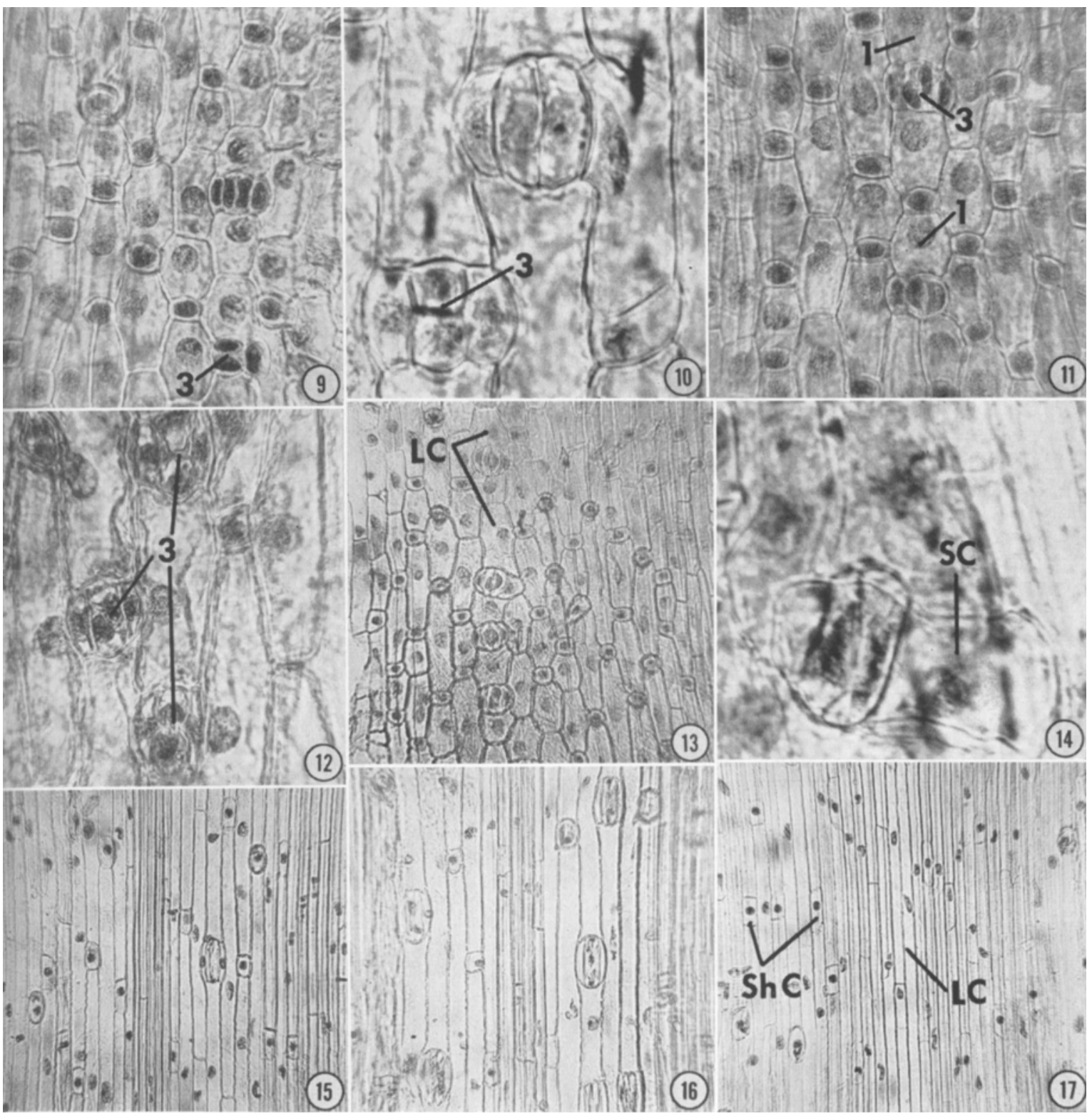

Fig. 9-17.-Fig. 9-12. Same series as in Fig. 4-8. Numbers referring to effects of the hormones are same as cited in legend for Fig. 4-8.-Fig. 13, 14. Epidermal peels from IAA-treated p-1 internodes, illustrating greatly promoted lateral expansion of alternating long cells (LC) and of subsidiary cells (SC) of stomata. IAA was used at $10^{-3} \mathrm{M} .-\mathrm{Fig}$. $15-17$. Epidermal peels from $\mathrm{GA}_{3}$-treated p-1 internodes $\left(30 \mu \mathrm{M} \mathrm{GA}_{3}\right)$.-Fig. 15,16 represent peels from positions well above the I.M. where stomata are differentiated.-Fig. 17 is a peel taken from just above the I.M. The effects of $\mathrm{GA}_{3}$ on lengthening of long epidermal cells (LC) and of short cells (Sh C) are more pronounced in the I.M. locus.-Fig. 9, 11, 13, 15-17. $\times 175 .-F i g .10,14 . \times 615$. -Fig. $12 . \times 310$. 
guard cells (Fig. 12). They simply enlarge, sometimes in distorted fashion, as in the case of long epidermal cells. This change in the plane of cell division in GCMC's from longitudinal to transverse has also been reported in the leaves of Hordeum vulgare treated with $0.175-0.2 \mathrm{M}$ 2-mercaptoethanol by Stebbins et al. (1967). Coupled with this effect of IAA on plane of cell division is the frequent promotion by IAA of lateral cell enlargement in one or both of the subsidiary cells, far out of proportion to their normal enlargement (cf. Fig. 2, 3 with 13, 14).

The effects of $\mathrm{GA}_{3}$ - In contrast with IAA, $\mathrm{GA}_{3}$ has no significant effect on lateral expansion of epidermal cells at any of the stages when these cells are elongating above the intercalary meristem. The diameters of $\mathrm{GA}_{3}$-treated cells are the same as those of water-incubated shoots (Kaufman, 1965b). However, $\mathrm{GA}_{3}$ at concentrations of 0.03 to $30 \mu \mathrm{M}$ causes a substantial in crease in the amount of cell lengthening in all enlarging and differentiating cells above the intercalary meristem (Fig. 15-17; $\mathrm{GA}_{3}$ at $30 \mu \mathrm{M}$ ). The promotion effect of $\mathrm{GA}_{3}$ on cell lengthening is greater in immature cells, such as those in the I.M. and just above it (Fig. 17), and less in more mature cells well above the I.M. (Fig. 15, 16). The long epidermal cells attain lengths up to eight times greater than in control tissue (cf. Fig. 2, 3 with 17). This augmentation in cell length can also be seen in differentiating stomata

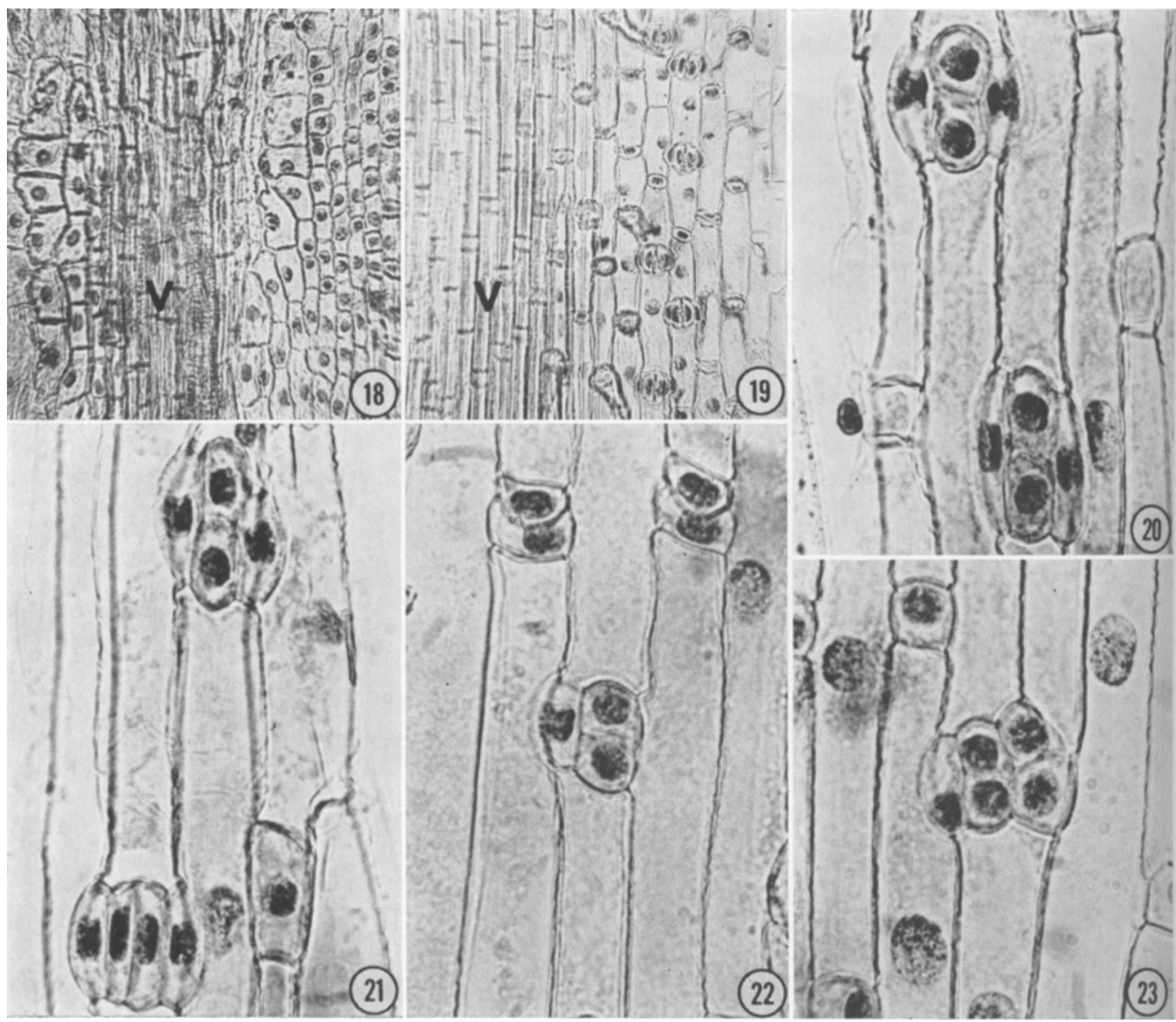

Fig. 18-23.-Fig. 18, 19. Epidermal peels from internodes treated with $\mathrm{GA}_{3}(30 \mu \mathrm{M})$ plus IAA (10 $\left.{ }^{-3} \mathrm{M}\right)$, illustrating in Fig. 18 the greatly promoted lateral expansion of cells in files located on either side of a vascular bundle (V), and in Fig. 19 the much more subtle expansion of comparable cells (long epidermal cells alternating with the idioblasts) in files located midway between the vascular bundles.-Fig. 20-23. Peels from p-1 internodes treated with GA $(30 \mu$ M) plus IAA $\left(10^{-3} \mathrm{M}\right)$. Each figure illustrates how IAA can alter the plane of cell division in guard cell mother cells of developing stomata. A normal-appearing stoma occurs in the lower left corner of Fig. 21. A stomatal apparatus in which a transverse division has also occurred in a subsidiary cell appears in the center of Fig. 23.-Fig. 18, 19. $\times 200 .-$ Fig. 20-23. $\times 500$. 
(Fig. 15), where both guard and subsidiary cells are slightly longer than in $-\mathrm{GA}_{3}$ controls.

One of the significant effects of $\mathrm{GA}_{3}$ on the development of the epidermis in p-1 internode is its ability to arrest cell division activity in short cells which form cork-silica cell pairs and stomata. The net effect is that all one sees are series of long and short epidermal cells that have undergone accelerated elongation, as illustrated in Fig. 17. Thus, $\mathrm{GA}_{3}$ has effectively disrupted normal cell differentiation in these cells. Even in short cells which normally form trichomes, where no cell division is involved, differentiation is arrested. This contrasts with IAA, which does not block cell division but may cause a change in plane of cell division to occur in cells that normally do not divide further, i.e., in the long epidermal cells.

The effects of combinations of IAA and $\mathrm{GA}_{3}$ In these experiments, IAA was used at concentrations which give maximal $\left(10^{-3}, 10^{-4} \mathrm{M}\right)$, intermediate $\left(10^{-5}, 10^{-6} \mathrm{M}\right)$, minimal $\left(10^{-7} \mathrm{M}\right)$, and no suppression $\left(10^{-9}, 10^{-10} \mathrm{M}\right)$ of $\mathrm{GA}_{3}$-promoted growth in p-1 internode (Table 1). The $\mathrm{GA}_{3}$ concentration was kept constant at $30 \mu \mathrm{M}$. The following are observations on the effects of these IAA plus $\mathrm{GA}_{3}$ treatments on patterns of cell enlargement and cellular differentiation in developing internodal epidermal cells.

IAA at high concentration $\left(10^{-3}, 10^{-4} \mathrm{M}\right)$ Under these conditions, IAA clearly overrides the effects of $\mathrm{GA}_{3}$ on cell expansion. The most obvious effect of the combination treatment is that IAA reduced $\mathrm{GA}_{3}$-promoted cell lengthening (cf. Fig. 15, 16 with 18, 19). The number of cells per epidermal cell file under these conditions is considerably greater than that of $+\mathrm{GA}_{3}$ control (average 236 compared with 199 cells per file, respectively). The second primary effect is that epidermal cells near vascular bundles are more laterally expanded, while those midway between the bundles are much less laterally expanded (Fig. 18, 19). This response was also observed in treatments with IAA alone. The third effect is that the plane of cell division in the GCMC's is altered (Fig. 20-23); in treated cells, it is usually transverse instead of in the normal longitudinal plane. From these observations it is clear that IAA at high concentrations, in the presence of $\mathrm{GA}_{3}$, effectively blocks the action of $\mathrm{GA}_{3}$ on both cell expansion and on cell differentiation.

IAA at intermediate concentrations $\left(10^{-5}\right.$, $10^{-6} \mathrm{M}$ ) - This treatment also reflects the dominance of IAA effects over those of $\mathrm{GA}_{3}$. However, lateral cell expansion is not so greatly promoted as with higher concentrations of IAA. In Fig. 24,25 it is apparent that there has been some widening of the developing long epidermal cells and even an occasional longitudinal division in these cells. However, the continuity of epidermal cell files is not disrupted nearly as much as with the higher auxin treatment (cf. Fig. 18, 24). The lengthening of long epidermal cells has not been markedly affected by this combination of IAA and $\mathrm{GA}_{3}$, similar to the $10^{-3}, 10^{-4} \mathrm{M}$ IAA $+\mathrm{GA}_{3}$ treatment. In both instances $\mathrm{GA}_{3}$ has only slightly promoted cell lengthening. Cell differentiation is not altered by the intermediate IAA $+\mathrm{GA}_{3}$ treatment. In stomata (Fig. 26, 27) the plane of cell division in the guard cell mother cell is normal; the only alteration is a substantial ballooning of the guard cells, which is an effect of IAA on the expansion of these cells. The differentiation of trichomes and of cork-silica cell pairs is apparently not affected by IAA at this concentration (Fig. 28,29 . With this treament it is apparent that IAA again predominates over $\mathrm{GA}_{3}$ as far as effects on cell expansion and cell differentiation are concerned. IAA not only significantly suppresses $\mathrm{GA}_{3}$-promoted lengthening of $\mathrm{p}-1$ internode at these concentrations; it also substantially reduces the effect of $\mathrm{GA}_{3}$ on cell division and cell lengthening and has little effect on cell differentiation.

IAA at minimal concentration $\left(10^{-7} \mathrm{M}\right)$ - In contrast with intermediate concentrations of IAA plus $\mathrm{GA}_{3}$, levels of IAA which cause minimal suppression of $\mathrm{GA}_{3}$-promoted growth $\left(10^{-7} \mathrm{M}\right)$ have only a slight effect in distorting the normal pattern of cell expansion in enlarging epidermal cells at the base of p-1 internode (Fig. 30). Some IAA effects can be discerned in stomata files just above the base of the internode (Fig. 31), where greater than normal cell expansion occurs in long epidermal cells and in the guard cells of differentiating stomata. In cork-silica cell files midway between vascular bundles there is little evidence for the occurrence of IAA-augmented lateral cell enlargement. Even the expansion of cork cells and silica cells in these files appears to be normal (Fig. 32).

With this combination of IAA and $\mathrm{GA}_{3}$, it is clear that $\mathrm{GA}_{3}$ overrides IAA in its effects on cell expansion in cell files located in the I.M. The I.M. cells shown in Fig. 30 are many times longer than comparable I.M. cells in untreated internodes. Moreover, $\mathrm{GA}_{3}$ has blocked the occurrence of asymmetric divisions which normally start the differentiation of idioblasts in internodal epidermis. Instead of dividing, these cells (just above the I.M.) continue to elongate. From these observations, with this particular combination of IAA and $\mathrm{GA}_{3}, \mathrm{GA}_{3}$ is the hormone which causes an alteration in patterns of cell expansion and cell differentiation at and just above the I.M. The effects of IAA, while not as obvious as with higher concentrations of IAA, are primarily seen in differentiating stomata files well above the I.M. 


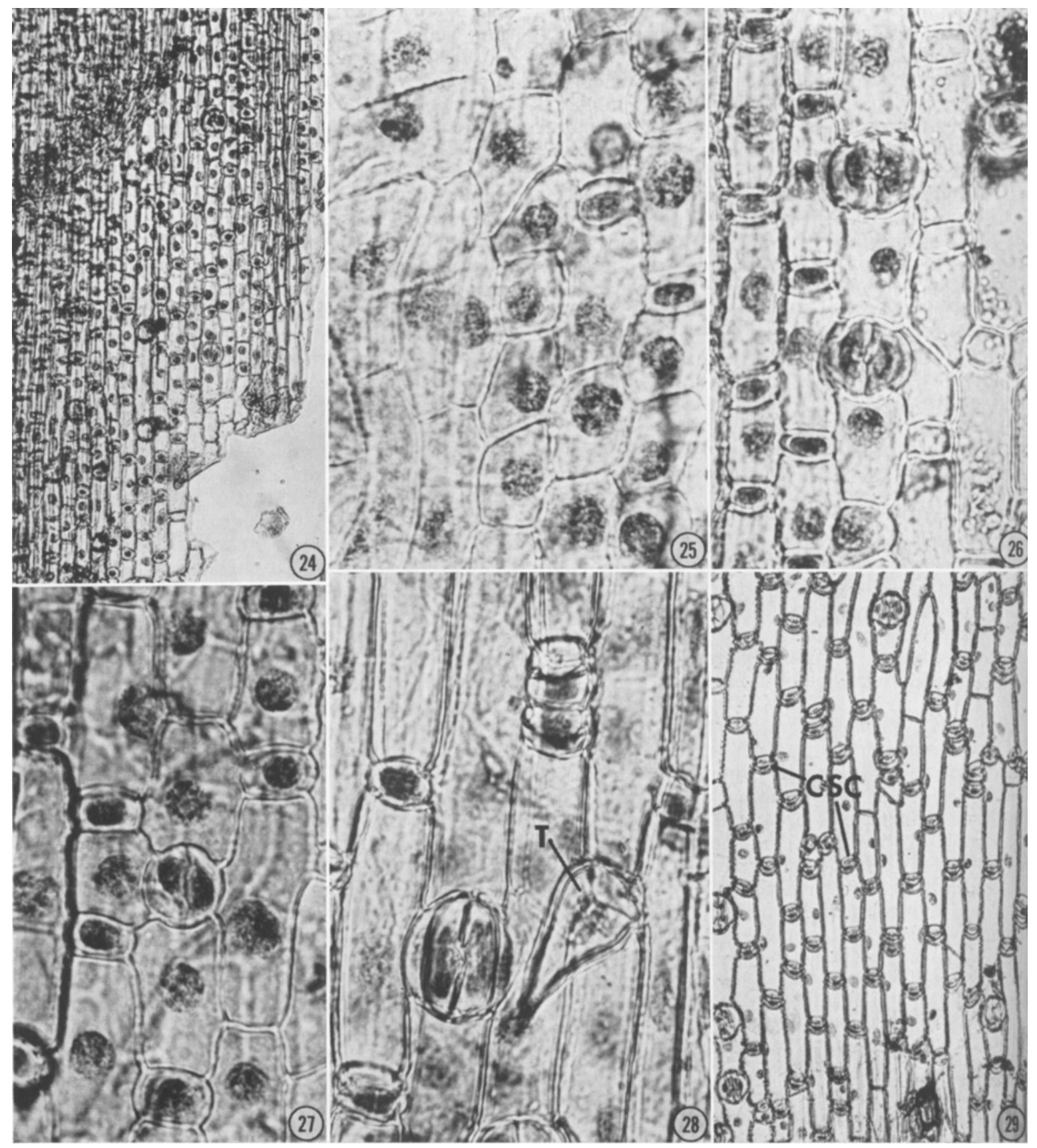

Fig. 24-29. Epidermal peels from p-1 internodes incubated in $\mathrm{GA}_{3}(0.03 \mu \mathrm{M})$ plus IAA $\left(10^{-5} \mathrm{M}\right.$ in Fig. $25,27,28 ; 10^{-6} \mathrm{M}$ in Fig. 24, 26, 29). In Fig. 24-27, promotion of lateral expansion of the alternating long cells by the IAA can be seen coupled with marked promotion in the expansion of stomata guard cells in Fig. 26, 27. Differentiation of trichomes (T) (Fig. 28) and cork-silica cell pairs (CSC) (Fig. 29) is not markedly impaired by these treatments. -Fig. 24, 25, 29. $\times 150$. Fig. 26-28. $\times 610$.

IAA at subminimal concentrations $\left(10^{-9}\right.$, $10^{-10} \mathrm{M}$ ) - With this combination of auxin and $\mathrm{GA}_{3}$, the epidermal cells show no effects of auxin. They respond as if treated with $\mathrm{GA}_{3}$ alone. This is most apparent at the base of the internode in the locus of the I.M., where no asymmetric divisions have occurred. Here, the I.M. cells are many times longer than normal (Fig. 33). This clearly is a gibberellin response and can be contrasted with that for $\mathrm{GA}_{3}$ alone (Fig. 17) and IAA alone (Fig. 4). This combination treatment also has profound effects on cell expansion just above the intercalary meristem. In this region the $\mathrm{GA}_{3}$ has caused alternating long and 

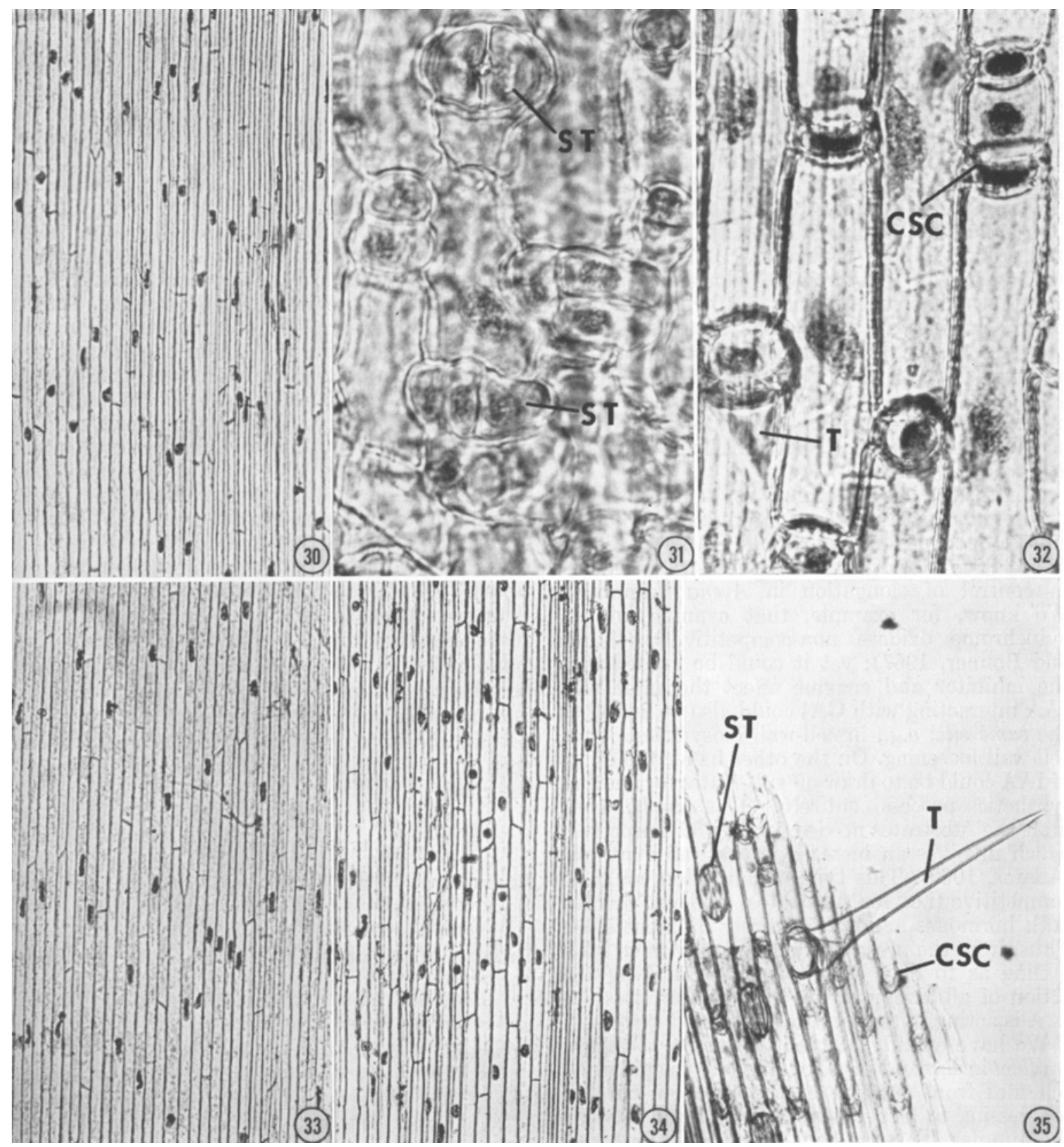

Fig. 30-35. Views of epidermal peels obtained from internodes treated with $\mathrm{GA}_{3}(0.03 \mu \mathrm{M})$ plus IAA $\left(10^{-7} \mathrm{M}\right.$ in Fig $30-32 ; 10^{-9} \mathrm{M}$ in Fig. 33-35.-Fig. 30. Base of p-1 internode where marked promotion of cell elongation in I.M. cells is most obvious. More distally IAA promotes cell expansion in differentiating stomata (ST) (Fig. 31), and has no effect on development of cork-silica cell pairs (CSC) or trichomes (TR) (Fig. 32). - Fig. 33. Base of p-1 internode in I.M. where $\mathrm{GA}_{\mathbf{3}}$ causes marked promotion in elongation of I.M. cells; Fig. 34 shows comparable effects on long and short cells just above the I.M. In Fig. 35, the treatment has not affected the development of more differentiated cells, trichomes (TR), stomata (ST), or cork-silica cell pairs (CSC). -Fig. 30, 33-35. $\times 145 .-F i g .31,32 . \times 600$.

short cells to become greatly elongated (Fig. 33; cf. with Fig. 2, 3 for normal pattern). It also has effectively blocked any further cellular differentiation from occurring in the short cells (Fig. 34); i.e., it has blocked formation of stomata, corksilica cell pairs, and trichomes. At positions well above the I.M., where epidermal idioblasts were already differentiating at the time of treatment, this combination treatment has little effect on final stages of differentiation of these three types of idioblasts (Fig. 35). From these observations it is clear that the effects of this treat- 
ment are due to $\mathrm{GA}_{3}$ and that the responses are essentially confined to the base of $\mathrm{p}-1$ internode.

Discussion-In many plant systems exogenous auxin, when combined with gibberellin in physiological concentrations, has the effect of suppressing gibberellin-promoted longitudinal growth in intact internodes and in excised stem segments (Hillman and Purves, 1961; Kato, 1961; van Overbeek and Dowding, 1961; Katsumi, Phinney, and Purves, 1965; Kaufman, 1967). In Avena stem segments IAA promotes elongation growth only at high concentrations $\sim 10^{-4}$ M. However, these segments are very sensitive to $\mathrm{GA}_{3}$, such that linear growth is promoted at concentrations as low as $10^{-7} \mathrm{M} \mathrm{GA}_{3}$ (Kaufman, 1965b; 1967). IAA in combination with $\mathrm{GA}_{3}$ represses $\mathrm{GA}_{3}$-promoted growth, the extent of suppression being as much as $50 \%$ at $10^{-3} \mathrm{M}$ IAA and $\sim 10 \%$ at $10^{-7}$ M IAA (Table 1).

What is the basis for this effect of IAA on $\mathrm{GA}_{3}$ promoted growth in Avena internodes? It is difficult to deduce from our results (Table 1; Fig. 1) the relative sites of action for these two hormones in control of elongation in Avena internodes. We know, for example, that cyanide inhibits cytochrome oxidase non-competitively (Ikuma and Bonner, 1967); yet it could be argued that the inhibitor and enzyme affect the same site. IAA interacting with $\mathrm{GA}_{3}$ could also be acting at the same site; e.g., in cell-wall biosynthesis or in cell-wall loosening. On the other hand, the effect of IAA could be to draw off substrates for another synthetic process entirely. This could then limit the substrates needed for the "GA process," which involves an increase in cell-wall synthesis (Adams, 1969). This type of inhibition could be competitive (i.e., for substrates) and yet involve both hormones acting at entirely different sites. Thus, from the present work we really have little inkling as to how IAA is actually braking the action of gibberellin or at what site or sites the IAA is acting in the gibberellin-treated system.

We have already alluded to the morphological gradient in size and shape of long cells in epidermal cell files from the site of the vascular bundles progressing to files which occur midway between the bundles. This gradient is expressed in terms of (1) relatively short and wide epidermal cells (long cell members) with strongly undulate walls in files containing stomata, which lie adjacent to the vascular bundles, and to (2) relatively long and narrow epidermal cells (again long cell members) with nearly straight walls in files which contain cork-silica cell pairs and trichomes, which lie midway between the bundles. This gradient is illustrated in Fig. 2, 3.

In treatments with exogenously supplied IAA and $\mathrm{GA}_{3}$, this morphological gradient is greatly disturbed. $\mathrm{GA}_{3}$ alone causes all of the cells just above the I.M. to elongate (Fig. 17), while IAA alone causes these same cells to widen at the "expense" of lengthening, particularly near the vascular bundles (Fig. 4). When IAA and $\mathrm{GA}_{3}$ are combined and supplied in physiological concentrations, one obtains a gradient in epidermal cell files which essentially mimics the above natural gradient, except that it is more pronounced (cf. Fig. 2, 3 with 24, 27-29). The future long cells near the vascular bundles are particularly sensitive to the IAA in this treatment; the cells midway between the bundles do not expand nearly as much and elongate greatly in response to the $\mathrm{GA}_{3}$. These experimental data suggest that an interaction of gibberellin and auxin could be operating to control cell expansion patterns across the internode in the locus above the intercalary meristem. More specifically, they suggest that IAA at minimal concentration $\left(\sim 10^{-7} \mathrm{M}\right)$ still exerts an effect on stomata files near the vascular bundles and does not affect the rest of the cells. This could explain why cells in these files are wider and shorter than their counterparts in files midway between the bundles. Thus, one can interpret these data in terms of a difference in sensitivity of enlarging epidermal cells above the intercalary meristem to IAA and $\mathrm{GA}_{\mathbf{3}}$. The cells near the vascular bundles would be more sensitive to IAA and those between the bundles less sensitive to IAA and more sensitive to gibberellin type hormones. This interpretation is compatible with the experimental data and is a possible basis for explaining the natural pattern seen in the epidermal system of the untreated internode.

\section{LITERATURE CITED}

Adams, P. A. 1969. Studies on gibberellic acid-induced growth in Avena stem segments. Ph.D. diss,, Univ. Michigan, Ann Arbor.

Hrluman, W. S., and W. K. Purves. 1961. Does gibberellin act through an auxin-mediated mechanism?, p. 589-600. In 4th Int. Conf. Plant Growth Regulat. Iowa State Univ. Press, Ames.

IkUma, H., AND W. D. Bonner, JR. 1967. Properties of higher plant mitochondria. III. Effects of respiratory inhibitors. Plant Physiol. 42: 1535-1544.

KATO, J. 1961. Physiological action of gibberellin with special reference to auxin, p. 601-609. In 4th Int. Conf. Plant Growth Regulat. Iowa State Univ. Press, Ames.

Katsumi, M. B., B. O. Phinney, and W. K. Purves. 1965. The roles of gibberellin and auxin in cucumber hypocotyl growth. Physiol. Plant. 18: 462-473.

KaUfman, P. B. 1965a. The effects of growth substances on intercalary growth and cellular differentiation in developing internodes of Avena sativa. I. The effects of indole-3-acetic acid. Physiol." Plant. 18: 424-443.

- 1965b. The effects of growth substances on intercalary growth and cellular differentiation in developing internodes of Avena sativa. II. The effects of gibberellic acid. Physiol. Plant. 18: 703-724. 
-1 1967. Role of gibberellins in the control of intercalary growth and cellular differentiation in developing Avena internodes. Ann. N. Y. Acad. Sci. 144: 191-203.

, N. Ghosheh, and H. Ikuma. 1968. Promotion of growth and invertase activity by gibberellic acid in developing Avena internodes. Plant Physiol. 43: 2934.

Overbeek, J. van, and L. Dowding. 1961. Inhibition of gibberellin action by auxin, p. 657-663. In 4th Int. Conf. Plant Growth Regulat. Iowa State Univ. Press, Ames.

Stebeins, G. L., S. S. Shah, D. Jamin, ANd P. JuRA. 1967. Changed orientation of the mitotic spindle of stomatal guard cell divisions in Hordeum vulgare. Amer. J. Bot. 54: 71-80.

Thimann, K. V. 1937. On the nature of inhibitions caused by auxin. Amer. J. Bot. 24: 407-412. 